\title{
SURINAAMSE ONDERWIJSZORGEN
}

DOOR

\section{H. VAN BOHEEMEN}

Het is, voor zover ik het nu zien kan, een hachelijke onderneming, een publicatie over "Onderwijszorgen" in Suriname de wereld in te sturen. Niet om het onderwerp zelve; dat is even belangrijk als de oplossing van de moeilijkheden zwaar. Maar Suriname staat zó in het brandpunt van belangstellende onderzoekers en het aantal rapporten en studies over de verschillende aspecten van Suriname's moeilijkheden wordt zó groot, dat men huivert er nog een aan toe te voegen.

Ik zeg dit niet om de draak te steken met al dat gepubliceer; integendeel - ik beschouw het als een noodzakelijk onderdeel van het ,,research work", dat aan de werkelijke plannen voor Suriname's opbouw vooraf dient te gaan.

Deze publicatie is óók niet bedoeld om nieuwe wegen te wijzen die kunnen voeren naar een oplossing van de talrijke problemen op onderwijsgebied. De voor vele jaren richting-gevende bijdrage daartoe is geleverd door de heer W. H. D'HAENS in zijn Rapport inzake de reorganisatie van het onderwijs in Suriname, dat begin 1947, na een zesmaands verblijf van de auteur in Suriname, tot stand kwam. In mijn functie van Directeur van Onderwijs tracht ik aan de in dat rapport neergelegde voorstellen een begin van uitvoering te geven, zodat een publicatie tot dat zelfde doel weinig reden van bestaan zou hebben.

Dat ik hier het een en ander heb neergeschreven is meer het gevolg van een ontdekking, die ik deed tijdens een kort verlof in Nederland. Bij gesprekken met velen, die in Suriname en speciaal in het Surinaamse onderwijs geinteresseerd waren, bleek mij de wel zeer grote onbekendheid met wat dit deel van 
het Koninkrijk voor zorgen heeft. Zaken, waaraan ik na een driejarig verblijf gewoon was geraakt, wekten de grootste belangstelling en het was tijdens een van die gesprekken, dat ik de suggestie kreeg: schrijf eens over die dingen; wij weten er hier zo weinig van.

Zo is het begonnen. Het doel is hiermede gelijk bepaald: belangstelling wekken in Nederlandse kringen. Deze belangstelling kan nooit groot genoeg worden. Suriname heeft ze dringend nodig, omdat uit die belangstelling het besef kan groeien, dat Suriname juist in de eerste jaren van zijn zelfstandigheid begrip en daadwerkelijke steun van node heeft. Die steun kan - zeker op onderwijsgebied - geheel door Nederland verleend worden en zij zal, voor zover ik er over kan oordelen, met dankbaarheid aanvaard worden door allen, die het wel menen met hun land.

WAT IK VOND

L a n d en volk

Dit wordt geen geschiedkundig overzicht; wie voor de geschiedenis van Suriname belangstelling heeft moge ik verwijzen naar het proefschrift van prof. dr R. A. J. vaN LIER: Samenleving in een grensgebied. Speciaal over het onderwijs gaat het proefschrift van dr J. H. E. FERrIER: De Surinaamse samenleving als een sociaal-paedagogische opgave.

Toch is voor de Nederlandse lezer een korte inleiding in de Surinaamse samenleving wel nodig. Deże samenleving immers is zo gecompliceerd en wijkt in vele opzichten zo af van de daaromtrent heersende meningen in Nederland, dat een enkel woord er over wel op zijn plaats is.

Om te beginnen: de Surinaamse samenleving neemt maar een klein deel in beslag van het gehele gebied, dat meer dan vier maal zo groot is als Nederland. Practisch leven 180.000 mensen in de $50 \mathrm{~km}$ brede kuststrook; de overige 20.000 wonen wel verder het binnenland in, maar dan blijft er toch nog altijd een brede strook land over, dat nog maar nauwelijks bekend is. Enkele expedities (o.a. de bekende grensexpeditie van 1935 tot '38) drongen er in door, maar wat er van op de kaarten staat, is naar alle waarschijnlijkheid lang niet altijd juist. Zo leren kinderen in Nederland op school braaf van het Toemoekhoemakgebergte op de grens van Suriname en Brazilië, terwijl deskundigen mij verzekerd hebben, dat er eigenlijk van een gebergte geen sprake is. In de toekomst zullen we wel iets wijzer 
worden, als de luchtkartering, die nu nog maar tot de 4de breedtegraad heeft gewerkt, ook de rest van Suriname in kaart heeft gebracht.

Te weinig vond ik in Nederland het besef, dat Suriname in Zuid-Amerika ligt. Als ik - bij wijze van proef - vertelde dat ik in Zuid-Amerika werkte, dan dacht men aan Brazilië, Argentinië of Peru, hoe onwaarschijnlijk dit ook moest zijn voor een onderwijsman. Suriname ligt tussen de stroomgebieden van Amazone en Orinoco en al wat ik als jongen las over dat geheimzinnige Amazone-gebied vond ik soms, zij het in andere verhoudingen, terug in de jungle van Suriname, vaak niet eens zo ver van de hoofdstad verwijderd.

Toch is dat deel-zijn-van-Zuid-Amerika slechts in geografisch opzicht juist. Want het is fout aan Suriname te denken als een echt Zuidamerikaanse staat, d.w.z. beheerst door Indiaanse afstamming en de Spaanse beïnvloeding. Wel leven er in Suriname nog enkele duizenden Indianen, maar ze drukken hun stempel niet op het land, ook al zijn zij er de oorspronkelijke bewoners van. En van een Spaanse beïnvloeding is in Suriname nooit sprake geweest. Er waren Engelse en Franse invloeden, maar ten slotte is Suriname een stuk Zuid-Amerika geworden met een zo sterke Nederlandse inslag, dat een ieder, die bekend is in de andere delen van het vroegere koloniale rijk van Nederland er door wordt getroffen.

Wie in Nederland West-Indië noemt, denkt aan een Negerbevolking. Ook dat is voor Suriname maar gedeeltelijk juist. Wie ook maar één dag in Paramaribo heeft rondgelopen weet, dat er nog vele andere rassen zijn te vinden: Hindostanen, Javanen, Chinezen, om maar bij de voornaamste groepen te blijven. Zoals in vroegere eeuwen doorlopende invoer plaats vond van negerslaven om te voorzien in de behoefte aan werkkrachten op de plantages, zo werden na de afschaffing van de slavernij in 1863 talrijke contract-arbeiders aangeworven uit China, India, Java. Deze Aziaten vormen thans reeds de grootste helft van de reeds genoemde 180.000 inwoners en er is aanleiding voor de veronderstelling, dat zij straks een nog grotere meerderheid zullen vormen.

En daarenboven vinden wij nog vele afstammelingen van uit Brazilië gekomen Portugese Joden, Europeanen, mensen uit Madeira, uit de Libanon, en de personen die uit de talrijke menghuwelijken zijn voortgekomen. Wat ik hiervoren een Negerbevolking noemde, bestaat voor een zeer groot deel uit Creolen, 
de in Suriname gebruikelijke naam voor elke rasmenging, waarbij het negerras betrokken is. Begrijpelijkerwijs kunnen dus de verschillen tussen de Creolen onderling zeer groot zijn.

Behalve met deze bevolkingssamenstelling, hangen de onderwijsproblemen ten nauwste samen met de wel zeer eigenaardige spreiding van de bevolking over het bewoonde gebied. Algemeen wordt aangenomen, dat bijna de helft van de bevolking is samengetrokken in de hoofdstad Paramaribo; de andere helft is verspreid over de rest van het land. Dit betekent, dat er buiten enkele centra als de mijnbouwnederzettingen Moengo en Paranam, en het plaatsje Nieuw Nickerie, bijna nergens een voldoend aantal mensen dicht genoeg bij elkaar woont om een centrum te vormen. Het spreekt vanzelf dat dit alleen al de onderwijsvoorziening in hoge mate bemoeilijkt. Daar komt nog bij, dat het verkeer uiterst primitief is op vele plaatsen. Er is een soort stoomtram, die ruim $130 \mathrm{~km}$ Zuidwaarts het binnenland invoert; er zijn enkele wegen waarlangs autobussen rijden, maar verder heeft het verkeer plaats langs smalle paadjes, die in de regentijd ware modderpoelen zijn, of over de rivieren, in roeiboten of in korjalen.

Bij dit alles zijn de Indianen en de Bosnegers buiten beschouwing gelaten. Voor zover zij wonen in het bewoonde gebied verschillen hun problemen niet van die der overige groepen. Voor hen die in de jungle boven de vallen in de rivieren wonen lagen de zaken tot nu toe wel heel anders. Deze Bosnegers vormen een gemeenschap (of gemeenschappen) op zichzelf; een staat (of staảtjes) in een staat, erfenis uit de tijd dat de weggelopen slaven een zekere mate van onafhankelijkheid verwierven. Dat dit in de naaste toekomst zal veranderen, staat voor mij vast. Dit is echter een probleem op zich zelf, politiek, economisch, sociaal. Tot nu toe vielen zij zo goed als buiten de bemoeienissen van „Onderwijs”, maar lang zal dat niet meer zo blijven.

Het ond erwijs

Wat vond ik aan onderwijs, toen ik voet aan wal zette? Alweer een zo merkwaardig samengesteld geheel, dat een overzicht noodzakelijk is, wil er ook maar iets begrepen worden van de thans in gang zijnde reorganisatie. Pas nu, na een vierjarig verblijf, zie ik heel duidelijk wat het onderwijs in Suriname vóór 1948 (het jaar waarin met de reorganisatie werd begonnen) karakteriseerde. Daar was in de eerste plaats een diepe scheidingslijn tussen de onderwijsvoorziening van de stad en daarbuiten. 
Buiten, dat is ,,in het district”, zoals dat in Suriname heet. Bestuurlijk is het land n.l. verdeeld in een aantal districten; de stad Paramaribo is er een van, maar wordt nooit met die naam aangeduid. De meer eigenlijke districten zijn (van West naar Oost) Nickerie, Coronie, Saramacca, Suriname, Commewijne en Marowijne.

In het district werd Beperkt Lager Onderwijs (B.L.O.) gegeven. Ik heb zelden een juister naam gezien; in alles was dit onderwijs beperkt: in het leerplan, in de kwaliteit der leerkrachten, in de betaling van deze laatsten. Het leerplan gaf lezen, rekenen, schrijven en een vak, dat heel mooi van naam en heel goed bedoeld was: Suriname-kennis. Aan de school werkten bijna uitsluitend de laagst bevoegden (met de alleen in Suriname en in de Ned. Antillen bekende 4de rang of hulponderwijzersakte) of in het geheel niet-bevoegden (de zg. districtskwekelingen). Wie aan een districtsschool geplaatst werd, kreeg slechts twee periodieke verhogingen toegekend van de veertien, die zijn collega's in de stad konden verwerven.

Het B.L.O. was een bezuinigingsproduct, trouwens tot in de tweede wereldoorlog toe leed elke overheidsbemoeienis in Suriname onder de loodzware druk van altijd maar weer te moeten bezuinigen. De op zich zelf juiste stelling, dat kinderen in de districten, kinderen van Aziatische landbouwers merendeels, andere onderwijsbehoeften hebben dan de kinderen in de stad, werd geheel misvormd door hun minder en minderwaardig onderwijs te geven. Het werd ten slotte een verwaarlozing van het districtskind; een verwaarlozing die een des te onaangenamer aspect kreeg doordat de Aziatische bevolkingsgroepen in de districten verre de meerderheid vormen. Weliswaar leven de verschillende bevolkingsgroepen in Suriname op voorbeeldige wijze naast elkaar, maar dat betekent toch weer niet dat er geen raciale gevoeligheden zouden bestaan.

Er is ook nog een proef geweest met desa-scholen voor de Javanen. Misschien had hier iets van terecht kunnen komen als men had kunnen beschikken over eigen Javaanse leerkrachten èn als men op die desa-school een vervolgschool had geprojecteerd. Toen die laatste achterwege bleef was de desa-school duidelijk een minderwaardige school voor de Javaantjes en dezen voelden dat ook zo aan. Ik geloof dat er nog enkele van die schooltjes bestaan, d.w.z. er is een of ander pondokje en daarin komen zo af en toe kinderen bijeen die van een totaal onbevoegd persoon iets krijgen, dat in de verte aan onderwijs verwant is. Ik zeg met 
opzet ,ik geloof", want door de een of andere wonderlijke opvatting werden de desa-scholen niet bij het gewone onderwijs ingedeeld en had het onderwijsdepartement er niets mee te maken!

In de stad Paramaribo liep eveneens een diepe scheidingslijn en wel tussen de zg. betalende en de niet-betalende school. De betalende scholen waren de scholen voor U.L.O. en voor M.U.L. O., die een geheel andere organisatievorm vertoonden dan in Nederland bekend is. Zijn het daar vervolgscholen of -klassen òp de lagere school, in Paramaribo was dat anders. De ULOschool telde acht leerjaren en kon vergeleken worden met een zesjarige lagere school met nog twee kopklassen. De MULOschool telde eveneens acht leerjaren; het eerste leerjaar was gelijk te stellen met het derde leerjaar van een lagere school. De vier hoogste klassen konden dus beschouwd worden als een vier-jarige MULO-school. De nietbetalende school was een gewone zesjarige lagere school.

Er bestond een duidelijk en schrijnend verschil in de voorziening van beide schooltypen. De betalende school kreeg de beter bevoegde leerkrachten; de leerlingenschaal was belangrijk gunstiger (resp. 26 en 32 tegen 45 voor de niet-betalende school); de leerkrachten op de betalende school kregen, ook als zij in de in-feite-lagere-school-klassen onderwijs gaven, een hogere bezoldiging. Schreeuwend was de ongelijkheid tussen het onderwijs aan de kinderen van de arme stadsbewoners en aan die van de beter gesitueerden; zo ergens het begrip democratie zoek was, dan was het wel op dit terrein. Het verwonderlijkste was m.i. nog, dat het zo algemeen werd aanvaard. Kenmerkend was b.v. een actie van die beter gesitueerden, toen het Bestuur de leerlingenschaal wilde verhogen. Men deed toen het aanbod méér schoolgeld te betalen, als de leerlingenschaal voor hun kinderen niet gewijzigd werd. En men aanvaardde dit ook nog, waardoor men de scheiding nog dieper maakte.

Verdergaand algemeen vormend onderwijs was er niet. Wie verder wilde leren, moest naar buiten; dat was meestal naar Nederland. De besten van de MULO-abituriënten konden vaak mee in de vierde klas van de Nederlandse vijfjarige H.B.S.; de andere kwamen in de derde klas terecht. Wie de technische kant uit wilde kon terecht op de M.T.S. in Nederland. Wel was er in Suriname vakonderwijs in de vorm van een Geneeskundige school, aansluitend op de MULO-school. In ruim 7 jaar konden de jongelui worden opgeleid tot Surinaams Geneesheer, een bevoegdheid die in Nederland nog niet het recht geeft tot het uitoefenen van 
de geneeskunde; wie dat wil moet aan een Nederlandse universiteit afstuderen. Verder was er een machinistencursus, eveneens aansluitend op de MULO-school en een ambachtsschool, die geacht werd aan te sluiten op de lagere school. In 1948 werd nog de Surinaamse Rechtsschool opgericht, die opleidt tot jurist, notaris of hogere ambtenaar.

\section{WAT ER NOG MEER AAN MANKEERDE}

Ook al gaf ik in het voorafgaande enkele gebreken en misstanden bij het onderwijs, dan nog zou het totaal beeld te rooskleurig wezen, dat aan de hand van dat overzicht zou kunnen ontstaan bij de lezers. Ik kan mij daarom niet tot het beschrijven van de organisatie van het onderwijs beperken, maar moet iets dieper op de zaak ingaan.

Er zijn bij het onderwijs zoveel problemen, dat ik wel schiften moet. De allerbelangrijkste zijn m.i. die betreffende het milieu der kinderen, de voertaal bij het onderwijs, het schoolbezoek en de opleiding van de leerkrachten. Ik zou ze niet graag willen rangschikken naar belangrijkheid; de invloed van elk op de resultaten van het onderwijs is zo groot, dat het ook weinig zin zou hebben dat te doen. Als ik ze dus in de genoemde volgorde bespreek, houdt dit geen oordeel in.

\section{Het milie u}

Suriname is, zei ik hiervoor, een stukje Zuid-Amerika met een sterk Nederlandse inslag. Dit treft niet alleen bij eerste kennismaking, maar ook bij langer verblijf. De kennis van het Nederlands b.v. is wijd verbreid en vaak zeer behoorlijk, ook in de gewone volksklasse. Duidelijk is mij dat vaak gebleken na een of andere voordracht voor de radio; uit het gewone volk kwamen dan de bewijzen van instemming met wat ik gezegd had. In het publieke leven worden maatstaven aangelegd, die ook de Nederlandse samenleving kenmerken.

Toch zijn er uiteraard grote verschillen: de omgeving, waarin het Surinaamse kind opgroeit, verschilt hemelsbreed met die van het Nederlandse kind. Zijn huis, zijn voedsel, zijn kleding, zijn spelletjes, zijn vermaak, het is alles anders. En zij verschillen niet alleen met wat.Nederland te zien geeft, maar ook onderling zijn de verschillen zeer groot. Een kind uit een Creools milieu in de stad groeit heel anders op dan dat in het district; de Hindostaan, de Javaan, de Creool in de districten verschillen onderling weer zeer sterk. 
Niet minder groot zijn andere verschillen en dan denk ik aan het gewone Nederlandse gezin en dat van de Creool, waarin de positie van de moeder zo overwegend is en de vader vaak afwezig. Ik denk aan de verschillen in godsdienstige achtergronden: de Creool, of protestant of katholiek, maar veel met reminiscenties uit vroegere omgeving; de Aziaten, Hindoe òf Islamiet.

Welnu, al deze kinderen hebben tot nu toe - enkele lofwaardige uitzonderingen daargelaten - onderwijs genoten aan de hand van zuiver Nederlandse methoden, verwerkt in zuiver Nederlandse boekjes. Men behoeft waarlijk geen onderwijsman te zijn om zonder meer te begrijpen, hoe fataal dit heeft gewerkt op de resultaten van het onderwijs. Want het gaat niet alleen om de anecdotische waarde van het bekende verhaal over het negerjongetje, dat onaandoenlijk opschrijft: mijn zusje is blond; noch om het evenzeer bekende leeslesje over Paultje, die op reis gaat en zo blij is, dat hij een hoekraampje getroffen heeft in de trein - gelezen door een Indiaans kereltje. Het gaat om het belangrijke feit, dat er met geen mogelijkheid enige belangstelling kan ontstaan bij de leerlingen voor deze leer- en leesstof en dat dus de resultaten van het onderwijs mede hierdoor ver beneden peil blijven.

Ik heb nooit dieper de afgrond beseft tussen het eigen milieu dezer kinderen en dat in de leesboekjes dan bij een bezoek aan het district Nickerie. De Districts-Commissaris nam me in denamiddag mee naar een Hindostaans feest, dat al enkele dagen duurde en nog steeds niet uit was. Elke middag werd er een gedeelte uit de Ramayana vertoond; prachtig uitgedost zaten of liepen de hoofdfiguren uit dit eeuwenoude verhaal rond op een afgesloten stukje land. Er om heen zaten de toeschouwers, oud en jong; ze keken toe en luisterden naar de man, die telkens een stuk uit het verhaal reciteerde. Opwinding bracht de strijd tussen de apenkoning en zijn tegenstanders, terwijl de potsenmakers zorgden voor de nodige hilariteit. Ik kreeg naast de Districts-Commissaris een ereplaats, maar na een poosje keek ik meer naar de toeschouwers dan naar het spel, dat voor mijn Europese begrippen niet zo erg boeiend was. Maar de jeugd om me heen leefde mee met glinsterende ogen. En toen dacht ik opeens: die kinderen lezen morgen in het boekje van Ot en Sien....

$\mathrm{Nu}$ moet ik eerlijkheidshalve verontschuldigingen aanvoeren. Schoolboekjes maken is een zakelijk bedrijf en een winstgevend object is een eigen schoolboekje voor Suriname nooit geweest; dat is het zelfs nu nog niet. Van de ca 33.000 schoolkinderen in het 
land bezoeken er 30.000 de zes klassen van de lagere school. Dat aantal moeten we weer in drieën delen, want we hebben naast openbare ook katholieke en prostestants-christelijke scholen. Delen we die uitkomst nog eens door zes (een nogal ruwe en onjuiste berekening uiteraard) dan komen we tot aantallen, die voor geen enkele uitgever enige aanlokkelijkheid bezitten. En zo gebruikte men maar boekjes, die in Nederland gebruikt werden. De fout ligt m.i. niet bij de uitgevers, maar bij hen die deze materie blijkbaar alleen maar op zakelijke basis konden bekijken. Daardoor is een achterstand ontstaan zo groot, dat er alleen met aller medewerking iets te bereiken valt. Hoe groot die achterstand is vertelt ons de Onderwijsvernieuwing, die zo dringend om aansluiting bij eigen milieu vraagt.

De voerta a l

Een wetenschappelijke uiteenzetting ga ik hier niet geven; dat laat ik gaarne aan meer deskundigen over. $\mathrm{Er}$ is literatuur te over voor hen, die zich speciaal voor dit probleem interesseren.

Veel tegenstand zal ik wel niet ondervinden bij de bewering, dat het kind in school ontvangen moet worden in zijn eigen taal. Dwingt de noodzaak in de school op den duur een andere taal tot voertaal te verheffen, dan zal dit langs een zorgvuldig overwogen methodische weg nagestreefd moeten worden.

Nederland kent het probleem der tweetaligheid nauwelijks. D.w.z. het probleem is er wel, maar veel aandacht heeft het tot op heden nooit gehad. Maar overal elders heeft het ruime aandacht getrokken, b.v. in België en het Zuidelijk deel van de Verenigde Staten. Ook in het Nederlands-Indië van vóór de oorlog, waar op Hollands-Inlandse, Hollands-Chinese en zelfs op Hollands-Arabische scholen het Nederlands na een betrekkelijk korte tijd voertaal was. Dat dit kon, was voor een groot deel te danken aan het werk van dr G. J. Nieuwenhuis op dit gebied.

Toen ik dan ook, na een vrij lange diensttijd in de Oost, in 1946 in de West arriveerde, was ik wel zeer verbaasd te bemerken, dat het probleem der tweetaligheid als probleem blijkbaar niet bestond. Bijna zonder scrupules onderwees men de kinderen in de eerste klas reeds dadelijk in de Nederlandse taal volgens Nederlandse methoden, in Nederlandse boekjes. Het gevolg was, dat in die eerste klassen zeer geringe vorderingen werden gemaakt, zo gering, dat de meeste leerlingen de klas moesten doubleren; er waren er ook bij, die er drie jaar over deden. Dat was vooral het geval in de districten, waar men te maken had 
met kinderen, die geen Nederlands kenden, het vaak nog nooit gehoord hadden en van huis-uit óf Negerengels óf Hindi óf Javaans spraken! De meeste kinderen kwamen dan ook gedurende hun schooltijd niet verder dan de derde of vierde klas; dan werden ze twaalf jaar en verlieten de school om te gaan werken op het land of in huis, de meisjes vaak om spoedig te trouwen.

Ik bemerk, dat ik in de verleden tijd geschreven heb onder invloed van het jaartal 1946, maar ik had gerust - en helaas - de tegenwoordige tijd kunnen gebruiken. Hierop kom ik nader terug.

Het gevolg van dit langzaam de klassen doorlopen is de opmerkelijke pyramide-vorm van elke school, wederom vooral in de districten. Het eerste leerjaar telt b.v. 80 leerlingen (netjes onderverdeeld in a, b en c naar het aantal jaren, dat ze er al in doorbrachten), terwijl de 4de klas nauwelijks tien leerlingen telt, soms een enkel kind in de 5 de zit en de 6de helemaal ontbreekt.

Er zullen in het verleden ongetwijfeld wel eens stemmen zijn opgegaan tegen deze wijze van werken; ze moeten echter geklonken hebben als die eens roepende in de woestijn. Nog steeds begrijp ik niet dat men in de West nooit geprofiteerd heeft van het baanbrekende werk van dr NieuwenHuIS in de Oost, ook al ligt het probleem - en dus ook de oplossing - hier in Suriname ietwat anders. Er was in Suriname in 1946, voor zover ik heb kunnen ontdekken, één exemplaar van het bekende Bronnenboek van Nieuwenhuis - echter niet op het Departement van Onderwijs.

Hoewel in de districten dit alles wel heel duidelijk spreekt, is toch ook in de stad het aantal kinderen, dat op school komt met geen of zeer weinig kennis van het Nederlands vrij groot; alleen op de vroegere ULO- en MULO-scholen waren er maar weinig.

De tweetaligheid heeft in Suriname nog dit specifieke aspect, dat bij een betrekkelijk geringe schoolbevolking we niet te maken hebben met één, maar met meerdere soorten tweetaligheid. In de school hebben we als voertaal het Nederlands; in verbinding met de diverse omgangstalen krijgen we dus Negerengels-Hollands, Javaans-Hollands, Hindi-Hollands. En dit is nog maar een eenvoudige, schetsmatige voorstelling. Want een Hindostaans kind zal, als er in zijn buurt Creolen-kinderen wonen, thuis Hindi praten, met zijn speelgenootjes Negerengels en op school Nederlands.

Ik geloof, met vele anderen, dat deze twee- en soms meertaligheid geen nadelige invloed behoeft te hebben op de intellectuele vorming. Indien tenminste het probleem onderkend is en de methodiek er rekening mee houdt. En dat is nu juist in Suriname niet het geval geweest. 
Het schoolbezoek

Misschien had ik beter kunnen zeggen: het schoolverzuim. Want dáár gaat het om: het niet op school komen van zeer vele leerlingen, hetgeen vooral in de districten schrikbarende afmetingen aanneemt.

Ik maakte met dit probleem al dadelijk kennis na mijn aankomst in het land. Het nieuwe schooljaar stond voor de deur en er moest worden uitgemaakt hoe groot de personeelsformatie van elke school moest worden. Ik had dat wel meer bij de hand gehad en meende ook hier met een eenvoudig deelsommetje: aantal leerlingen gedeeld door het getal van de leerlingenschaal, klaar te zijn. Het bleek echter een vrij ingewikkelde berekening te vereisen: eerst moest het gemiddelde verzuimpercentage over het afgelopen schooljaar berekend worden - daarmee moest het aantal ingeschreven leerlingen verminderd worden - vervolgens mocht ik er weer 40 procent bij doen en kon pas aan mijn deling beginnen, als ik er eerst nog de leerlingen had afgetrokken, die in het afgelopen schooljaar minder dan 4 dagen per maand de school hadden bezocht.

$\mathrm{Al}$ deze dingen waren nodig geworden door het ontzettend grote verzuim in de districten. Verzuimpercentages van 20 of 30 waren gewoon; er waren ook scholen met 40 of 50 procent verzuim. En men begrijpe dit goed: het zijn niet steeds dezelfde kinderen die thuis blijven. De onderwijzer kan dus op een bepaalde dag van de week een geheel ander stel leerlingen voor zich hebben dan op een andere dag van de daaropvolgende week. Was het nog maar zo, zullen vele districtsonderwijzers verzuchten: dan had ik elke leerling in elk geval de halve schooltijd en behoefde ik mijn leerstof maar twee keer aan te bieden. Het is in werkelijkheid zo'n chaos-verwekkend verzuim, dat soms hoofdelijk onderwijs noodzakelijk is; het kan alleen nooit gegeven worden omdat er zovelen zijn, die allen weer in ontwikkeling verschillen.

Natuurlijk zijn er tal van oorzaken, die tot dit hoge verzuimpercentage aanleiding geven. De bewoners van de districten zijn een landbouwende bevolking; de rijstbouw, zoals die door Javanen en Hindostanen bedreven wordt, is alleen mogelijk en lonend wanneer ongeveer het gehele gezin meewerkt. Mannen, vrouwen, grotere jongens en meisjes werken op het veld; wat daarvoor te klein is past op het huis, op de bezittingen en op de allerkleinsten. De plant- en oogsttijd zijn dan ook de grote vacanties: er zou anders niemand op school komen. Jammer ge- 
noeg vallen nergens de planttijden, die nauw verband houden met de regens, gelijk en dus verschillen ook de oogsttijden. In hetzelfde district kan dat wel weken verschillen. En aangezien deze vacanties per district worden geregeld door de DistrictsCommissarissen, is meestal vlak voor en vlak na die vacanties het verzuim zo groot, dat men moeilijk van schoolbezoek kan spreken.

Een andere oorzaak is ongetwijfeld het ontbreken van wooncentra. De landbouwers wonen allen op hun percelen en die liggen naast elkaar langs de weg, soms vele kilometers lang. Het geeft niet waar de school gezet wordt; het grootste deel van de leerlingen moet toch grote afstanden lopen om de school te bereiken. Dat lopen geschiedt dan of in de brandende zon of in de stromende regen; de kinderen lopen door mul zand of zakken weg in de modder. De wat oudere meisjes zeulen jongere broertjes of zusjes mee, zo van drie, vier en vijf jaar. Onder de leerplichtige leeftijd, zult U zeggen? Natuurlijk. Maar ze kunnen niet thuis gelaten worden omdat de ouderen op het veld werken en dus spelen deze kleuters op het schoolerf, in een hoek van het schoollokaal of zitten als angstige vogeltjes in de bank naast grote zus. Ze zijn een wanhoop van de districtsonderwijzer, die ze toch niet weren kan. Als de kleintjes niet mogen meekomen, blijft de grote zus óók thuis.

Verder speelt ook armoede vaak een rol - gebrek aan nette en schone kleren: Vooral op de stadsscholen, waâr men dê kinderen zo netjes mogelijk naar toe probeert te sturen en waar vaak de armoede zo groot is. Vandaar dat op de stadsscholen ook nog verzuimpercentages voorkomen van vijftien! En vandaar ook, dat we Zaterdags geen school houden. Naast andere redenen is dit wegens de noodzaak het schoolpak te wassen en te strijken, om Zondags netjes naar de kerk en 's Maandags weer naar school tè kunnen gaan.

Toch is naar mijn overtuiging de allerbelangrijkste factor: het ontbreken van het besef bij de ouders - vooral in de districten - dat het naar school sturen van de kinderen een eerste ouderplicht is. Er zou een boekdeel te schrijven zijn over de oorzaken hiervan.

De opleiding van de leerkrachten

Volgens hedendaagse maatstaven is de opleiding van de leerkrachten nooit voldoende geweest. Toch moet ze een jaar of dertig geleden behoorlijk geweest zijn, want de generatie oudere 
onderwijzers telt in Suriname een aantal bekwame schoolmeesters. Dit kan gelegen hebben aan de toenmalige opleiders; het kan ook zijn dat de ,,bibit" voor de opleiding toen beter was dan daarna en het soort ,heilig vuur" bezat voor het ambt, dat eigenlijk iedere schoolmeester moet bezitten.

Het grootste kwaad in de onderwijzersopleiding was - en is helaas tot nu toe - de akte van hulponderwijzer, vroeger ,,vierde rang" geheten. Die vierde rang moet zelfs wat méér geweest zijn dan de latere hulponderwijzersakte; men kan dat nog wel merken aan wat ouderen. Een oordeel over deze hulponderwijzersakte kan alleen maar vernietigend wezen. Ze kan met vrij veel kans op succes behaald worden door kinderen, die pas geslaagd zijn voor het MULO-diploma. In de luttele weken tussen hun eindexamen en dat voor hulponderwijzer leren ze een boekje uit het hoofd over ,opvoedkunde"; ze kennen dan de woorden leergang en leerplan, klassikaal onderwijs, hoofdelijk onderwijs, met vele onderverdelingen zelfs. Ze kennen enkele artikelen van de Onderwijs-verordening uit het hoofd. Van lesgeven, van methoden, van methodiek weten ze niets, of enkele woorden. Ze kunnen de aanvallige leeftijd van 15-16 jaar hebben; slagen ze, darı staan ze in November voor de klas, terwijl ze er in Augustus nog zelf in zaten! Een enkele grappenmaker heeft wel eens examen gedaan uit de op één na hoogste klas van de MULOschool en slaagde. Daarna volgde hij trouw de hoogste MULOklas en werd door de onderwijzer met enigszins wrange humor als ,,kollega" aangesproken!

En... dit zijn in zeker opzicht nog de besten. Want zij hebben een ondergrond, waarop ze verder kunnen leren. Maar er zijn er ook, die geen MULO-opleiding hebben gehad en hun opleiding hebben ,genoten" aan de een of andere Normaalles, in de avonduren, gedurende twee jaar. Kunnen de MULO-abituriënten met een redelijke kans van slagen voor de onderwijzersakte doorgaan, de afkomelingen van de Normaallessen zijn praktisch veroordeeld hun hele leven hulponderwijzer te blijven. Immers vraagt het onderwijzersexamen kennis van de vreemde talen en van wiskunde, vakken, die de avondopleiding voor hulponderwijzer niet geeft.

Ja, en dan die avondopleidingen, ook voor de onderwijzers- en hoofdakte. Lessen door leerkrachten, die al een volledige dagtaak achter de rug hebben; lessen aan leerlingen, die eveneens de hele dag (en dat is in Suriname van 8 uur 's morgens tot 1 uur 's middags) voor de klas hebben gestaan, als ze bezig zijn aan onder- 
wijzers- of hoofdakte. Ik kan me ontslagen achten uiteen te zetten, hoe slecht deze avondopleidingen wel zijn moeten; dit is overbekend.

Er was - en gelukkig kan ik hier de verleden tijd gebruiken er was nòg een euvel aan de opleiding verbonden. En dat was, wat ik gemakshalve altijd maar intellectuele inteelt noemde. Men leidde elkaar op, examineerde elkaar en was de akte behaald, dan was men al gauw aan het opleiden en met wat geluk aan het examineren. Ik weet, dit kón niet anders; het onderwijs was bloedarm. Maar dat toevoer van vers bloed nodig was, zal niemand mij kunnen tegenspreken.

Het heeft weinig zin, nu achteraf nog te gaan napluizen, hoe eigenlijk al dit verkeerde is ontstaan en zo lang heeft kunnen blijven bestaan. Er zullen wel een aantal factoren hebben samengewerkt tot dit alles. Onderwijzers waren nu eenmaal nodig en omdat er nooit geld was in het verleden - men kan nòg kriegelig worden als men nagaat met hoe weinig geld men moest toekomen - moest het natuurlijk zo goedkoop mogelijk. Een slecht opgeleide onderwijzer behoefde uiteraard niet zoveel te verdienen; ik geloof dat ze eigenlijk nog teveel verdienden, want anders had men nooit zijn toevlucht genomen tot de zg. districtskwekelingen, die met een ,,salaris" van 25 gulden in de maand werden beloond en aangeduid werden met de veelzeggende naam van „,blotevoeters”. Deze kwekelingen hadden geen enkele opleiding gehad en ze studeerden ook niet voor een of andere bevoegdheid...

WAT ER GEDAAN WERD ... EN NOG MOET WORDEN GEDAAN

Ik zal in dit hoofdstuk proberen aan te geven, op welke wijze wij bezig zijn aan de verbetering van ons onderwijs en mij daarbij beperken tot de onderdelen, die ik hiervoor besprak. Het arbeidsveld is uiteraard veel ruimer.

De organis a tie

In het begin heb ik vermeld, dat in 1947 door de heer W. H. M. D'HAENS een rapport werd uitgebracht over de maatregelen, die getroffen moesten worden ter verbetering van het onderwijs: Dat rapport kreeg in Suriname ruime verspreiding en ondervond zo goed als geen tegenspraak. Het werd door het toenmalige. Bestuur aanvaard als grondslag voor een reorganisatie; hierdoor werd uitgedrukt, dat men wel in grote lijnen met de voorgestelde' plannen accoord ging, maar zich de vrijheid voorbehield er zo dat nodig mocht zijn - van af te wijken. 
Met ingang van het schooljaar 1948-1949 werden er in de rganisatie de volgende veranderingen aangebracht:

I De MULO- en ULO-school werden gesplitst, elk in een gewone lagere school en een afzonderlijke school voor ULO en voor MULO. De afgesplitste lagere school werd genoemd: school voor G.L.O.-A; dit in tegenstelling tot de reeds bestaande lagere scholen, die voortaan heten: scholen voor G.L.O.-B. Het verschil zit niet alleen in het niet en wel gratis toegankelijk zijn, maar ook in de verschillende taalbeheersing der leerlingen bij hun komst op school.

De ULO-school werd twee-jarig en is toegankelijk voor kinderen, die de lagere school met vrucht hebben doorlopen. De MULO-school werd vierjarig. Dit was niet overeenkomstig het rapport-D'HAENS, wel overeenkomstig de wens, die werd uitgesproken door de Staten van Suriname. De toelating tot de MULO-school werd in het eerste jaar vrij gelaten, hoewel de waarschuwing werd uitgegeven, wel degelijk toe fe zien op het gehalte der leerlingen. Toch bleek al spoedig, dat andere maatregelen nodig waren, niet alleen om te voorkomen, dat het M.U. L.O. een te grote en onverantwoorde omvang zou krijgen, maar ook om die leerlingen te weren, waarvan met grote zekerheid gezegd kon worden, dat zij dat onderwijs niet zouden kunnen volgen. $\mathrm{Na}$ adviezen ingewonnen te hebben bij schoolbesturen en onderwijzersverenigingen werd door de onderwijsleiding besloten, een toelatingsexamen in te stellen. Uiteraard stond de Surinaamse gemeenschap nog wat onwennig tegenover dit nieuwe en de eerste uitslag ( $57 \%$ slaagde) verwekte nogal wat beroering, tot zelfs in de Staten. In 1950 werd voor de tweede maal dat examen afgenomen en alhoewel het percentage geslaagden minder was dan het voorafgaande jaar, was er van enige reactie nauwelijks sprake.

Er werden nog enkele maatregelen genomen om te voorkomen, dat de MULO-school een school bleef, waarop men kon blijven zitten tot eeuwigheid en amen; er zaten in 1947 zelfs gehuwde mannelijke leerlingen op een MULO-school! Nu kunnen ze niet langer dan drie jaar over twee opeenvolgende klassen doen.

Van belang is ook de overeenstemming die bereikt is tussen de MULO-scholen van verschillende richting. Er wordt nu gewerkt langs uniforme richtlijnen en in 1952 zal voor het eerst een uniform eind-examen worden afgenomen. Dit is vooral belangrijk, nu de MULO-school geen eindschool meer is in Suriname, maar 
haar abituriënten opgenomen worden door Kweekschool en A.M.S.

II De oprichting van de Surinaamse Kweekschool en de Algemene Middelbare School (A.M.S.). Over de Kweekschool spreek ik later; over de A.M.S. zij hier vermeld, dat ze bedoeld is als een driejarige school, aansluitend op de eerste drie jaar van de MULO-school. Gestreefd wordt naar een einddiploma dat gelijke rechten zal geven als het diploma H.B.S. V B in Nederland. Er werkt een staf van volledig bevoegde leraren M.O. aan en het leerplan zal - tezamen met dat van het M.U.L.O. - niet veel verschillen van dat van de Nederlandse middelbare school, al behouden wij ons het recht voor er van af te wijken, indien en voor zover de plaatselijke omstandigheden dat vereisen. We streven niet naar een copie-achtige gelijkheid, maar naar gelijkwaardigheid.

Uiteraard weet nog niemand hoe de A.M.S. zal uitgroeien; er liggen nog tal van mogelijkheden, die bekeken moeten worden. Is b.v. niet een A-afdeling noodzakelijk? Of een gymnasiale afdeling ? De toekomst zal dat uitmaken. Voorlopig zijn we begonnen met niet minder dan drie eerste klassen. Een begin, dat misschien te mooi is. Maar ook hier zal de praktijk wel uitwijzen, welke kant we met het middelbaar onderwijs uit moeten.

III Het Beperkt Lager Onderwijs verdween als zodanig. Dat wil zeggen: de naam en de bepalingen, die evenzovele beperkingen inhielden. Het spreekt vanzelf dat er nog heel wat tijd nodig is, voor het onderwijs in de districten op een peil gebracht is, dat - gegeven de omstandigheden in de districten - aanvaardbaar is. Ik zeg dit met opzet wat voorzichtig, omdat ik te goed weet dat het misschien wel een hersenschim zal blijven, het onderwijs in de districten gelijk te krijgen met dat in de stad.

Het opheffen van de beperkende bepalingen bracht nog enkele moeilijkheden met zich. Het was vroeger zo, dat men, eenmaal in het bezit van de hoofdakte, zeker kon zijn van een plaats in de stad Paramaribo, om er niet meer vandaan te komen. Zelfs het bezit van de onderwijzersakte gaf in dit opzicht aardige kansen. Dit is nu geheel vervallen en deze veranderde personeelspolitiek heeft even tijd nodig gehad om in het corps aanvaard te worden. Toch kan reeds nu gezegd worden dat het besef aanwezig is, dat het huidige ideaal van elke Surinamer - de opbouw van zijn land - met zich brengt het ernstige streven ook de districten vooruit te brengen. Vooral de districten, zeggen velen, want zij vormen in economisch opzicht de basis van het land. 
$\mathrm{Het} \mathrm{milieu}$

Bijna zou ik in de verleiding komen om aan te geven, wat er gedaan kan worden ter verbetering van het milieu, waarin onze leerlingen opgroeien. Want als wij de stelling poneren, dat ons onderwijs moet aansluiten bij het milieu, dan vooronderstellen wij een goed, een verantwoord milieu. En heel veel Surinaamse milieu's kan ik niet goed, niet verantwoord noemen. Het typisch Creoolse milieu met zijn sterke moederbinding, ook als men volwassen is en met de mogelijkheid er op terug te vallen in tijd van ,,nood", acht ik persoonlijk een van de grootste hinderpalen voor de ontwikkeling van de Surinaamse gemeenschap. Hier ligt echter meer een taak van de volksopvoeder, een taak die ik in spreekbeurten en radio-praatjes tracht te vervullen. Maar waar deze bladzijden het onderwijs in engere zin betreffen, laat ik het schrijven daarover gaarne aan anderen over.

Het is trouwens wel duidelijk, dat er - zonder zich in de milieu-verbetering te verdiepen - genoeg gedaan kan worden om de grote fouten van het verleden te herstellen en in de toekomst te vermijden. Dat betekent o.m. het scheppen van geheel op Suriname ingestelde schoolboeken; hier helpen geen omwerkingen van op zich zelf goede Nederlandse boekjes.

Daarbij zijn een aantal eisen onafwijsbaar. In de eerste plaats zal de samensteller van die boekjes de Surinaamse gemeenschap en dus het Surinaamse kind goed moeten kennen. In de tweede plaats moet hij kunnen schrijven, voor kinderen. Verder zal hij op de hoogte moeten zijn van de nieuwste opvattingen ten aanzien van schoolboekjes; ik zou dit laatste ook zo kunnen zeggen: hij moet iets te pakken hebben van de onderwijsvernieuwing.

$\mathrm{Nu}$ is de grote moeilijkheid, personen te vinden die aan deze eisen voldoen. Ongetwijfeld telt Nederland voldoende goede schoolboekenschrijvers, maar helaas kent geen van hen de huidige Surinaamse samenleving. Er zijn zeer zeker Surinamers, die de Surinaamse samenleving en het Surinaamse kind goed kennerı, alhoewel dit geen eenvoudige opdracht is. Kent b.v. een Creoolse onderwijzer voldoende het milieu van het Hindostaanse of het Javaanse kind? Maar stel, dat we zo iemand ontdekken, dan zou hij niet alleen moeten kunnen schrijven, maar ook de nieuwe opvattingen inzake methodiek en didactiek moeten kennen.

Deze opgave is zwaar; ze is zo zwaar, dat we naast de erkenning van de noodzaak tot nieuwe schoolboekjes nog niet hebben kunnen komen tot zelfs maar een begin van de verwezenlijking. Wel wordt er ijverig naar een oplossing gezocht en we leven in de

West-Indische Gids XXXII 
hoop, spoedig met een en ander te kunnen beginnen. Het is met dit probleem als met zovele andere hier in Suriname: ze worden onderkend - men weet hoe ze aangepakt moeten worden maar de mensen, die het doen kunnen, die zijn nog niet gevonden.

Nodig zijn in de eerste plaats eigen leesboekjes; boekjes die naast leesstof uit eigen milieu's (ik gebruik hier met opzet het meervoud!) in de hogere deeltjes een inleiding moeten geven in de wereld daarbuiten. Dit is wenselijk, want we leven in feite geisoleerd en de jeugd kent de wereld buiten Suriname bijna uitsluitend door de Amerikaanse film - dus niet op zijn best. Nodig zijn verder aardrijkskunde- en geschiedenisboekjes, die de bestaande werkjes op dit gebied vervangen; deze zijn wel Surinaams ingesteld, maar voldoen in zeer vele opzichten niet aan de eisen, die we tegenwoordig aan dergelijke boekjes stellen. Dringend nodig is een eigen taalmethode, maar daar kom ik later op terug.

Men bedenke bij dit alles, dat het hier niet alleen gaat om de lagere school, maar ook om de ULO- en MULO-scholen. En voor een deel ook om ons nog jonge middelbare onderwijs. Zeker , voor een aantal vakken zijn hier de Nederlandse boeken zeer goed bruikbaar. Maar biologie, aardrijkskunde en geschiedenis b.v. vragen ook op deze scholen eigen visie en eigen methode van aanpakken.

Is er dus tot nu toe weinig resultaat positief bereikt, er wordt aan de andere kant sinds jaar en dag gehamerd op dit aambeeld: gebruik de boeken, die we helaas nog moeten gebruiken, met verstànd. Sla over, wat volkomen buiten het voơstellingsvermogen van de kinderen ligt. Versurinaams, waar dit maar mogelijk is en laat dus geen bosneger-jongen meer zeggen, dat zijn zusje blond is. Stel, waar mogelijk, zelf uw lees- en oefenstof samen. Sta boven het boek! We hebben er lezingen over gehouden - artikelen over geschreven, schoolbijeenkomsten over belegd. Toch blijft het resultaat beneden het noodzakelijke. Want ieder schoolman begrijpt, dat voor het opvolgen van deze raadgevingen een goed onderlegd onderwijzerscorps noodzakelijk is. En daar mankeert - men zie wat ik schreef over de onderwijzersopleiding - nog maar al te veel aan. Zo wijst de uiteindelijke oplossing naar een verbeterde onderwijzersopleiding - en niet alleen bij dit onderdeel.

De voerta a 1

In zijn proefschrift De Surinaamse samenleving als een sociaal- 
paedagogische opgave komt J. H. E. Ferrier tot de uitspraak, dat geen van de eigen talen der grootste drie bevolkingsgroepen ('t Negerengels van de Creolen, 't Hindi van de Hindostanen en 't Javaans van de Indonesiërs) voor een algemene voertaal in aanmerking komt. Als zodanig aanvaardt hij het Nederlands.

Ik geloof niet te veel te zeggen als ik beweer, dat dit ook de leidende gedachte bij het onderwijs gedurende de laatste zeventig jaar is geweest. De eerste inspecteur voor het onderwijs, dr H.D. BENJAMINS, heeft in de ruim dertig jaar van zijn ambtelijke loopbaan het onderwijs in deze geest geleid en zo is het gebleven tot op de huidige dag. Helaas heeft men er niet de onderwijskundige conclusie uit getrokken, die onvermijdelijk was als men ongelukken wilde voorkomen. $\mathrm{Nu}$ was dat nog te begrijpen in het verleden, toen het probleem der tweetaligheid nog niet de aandacht had van tegenwoordig. Dat men het ook in de latere jaren niet heeft onderkend, althans niet heeft getracht de bezwaren er van te ondervangen, is onvergeeflijk.

Reeds heb ik uiteengezet, wat de gevolgen zijn van het negéren der twee-, soms meertaligheid der leerlingen. Het is uitgesloten dat betere resultaten in de school verkregen zullen worden, zolang men de kinderen, die alleen maar hun eigen omgangstaal (talen) kennen, in het Nederlands ontvangt en onderwijst bij het op school komen. Wel is nodig, de kinderen zo spoedig mogelijk met het Nederlands als voertaal vertrouwd te maken. Met de nadruk op mogelijk. In tal van Hollands-Inlandse scholen in Nederlands Oost-Indië bracht men het in één jaar lagere school zover, dat in het tweede leerjaar het Nederlands als voertaal gebruikt kon worden. Daaraan was meestal een jaar in een zg. Voorklas vooraf gegaan.

Ik acht dit in Suriname evenzeer mogelijk, met dien verstande, dat we gebruik maken van de omstandigheid, dat de ouders in de districten de jonge kinderen toch al mee naar school sturen, waar ze een ware last zijn. Deze last kan in een voordeel omgezet worden, als wij deze kinderen een jaar of twee opvangen in een kleuterschool. In deze school moet als leidraad door alles, wat gedaan wordt, heenlopen dit doel: de kinderen vertrouwd maken met de Nederlandse klanken - met het Nederlandse woord. Deskundigen beweren, dat de leeftijd van 4 en 5 jaar daarvoor bij uitstek geschikt is.

Dit ,,vertrouwd maken” moet liefst zo onopzettelijk mogelijk geschieden; spel en zang zijn de aangewezen middelen. Heeft dit gedurende twee jaar plaats gevonden, dan kan in betrekkelijk 
korte tijd die ,vertrouwdheid" met het Nederlands omgezet worden in een zekere ,beheersing" en kan het Nederlands de voertaal bij het onderwijs worden. Dat hierbij een wetenschappelijk paedagogisch verantwoorde methode voor het aanvankelijk lees- en taalonderwijs een eerste voorwaarde is, spreekt vanzelf.

Een belangrijk aspect bij dit alles is, dat het m.i. een aflopend proces is. Ik bedoel dat er een tijd zal komen, dat dóór de school het Nederlands ook de omgangstaal is geworden van de gehele bevolking en daardoor het nationale bindmiddel, dat de zo heterogene bevolking van Suriname bindt tot een Surinaams Volk. Wat ras, eigen cultuur, godsdienst en omgangstaal scheiden, wordt door het Nederlands verbonden.

Ik grond deze optimistische verwachting op de ervaringen in het vooroorlogse Indonesië. Er was op Java reeds een generatie jongeren, opgevoed op de H.I.S. en zó vertrouwd met het Nederlands, dat dit de omgangstaal was in het gezin, dat ze met elkaar stichtten. De kinderen uit deze gezinnen spraken het Nederlands als hun moedertaal en het was voor deze kinderen, dat het reglement op de toelating tot de Europese scholen zodanig gewijzigd werd, dat zij er zonder speciale vergunning leerlingen van konden worden.

Zeker, ik weet dat dit proces in Indonesië onderbroken is door nationale sentimenten en revolutionnaire omstandigheden. Maar de mogelijkheid van deze gang van zaken is gebleken; ze blijkt trouwens vandaag de dag ook in Suriname. Het duidelijkste voorbeeld vormen de talrijke Hindostaanse families, die na een 75-jarig verblijf in dit land een verbluffend zuiver Nederlands spreken. Voor kinderen uit zulke gezinnen is het Nederlands geen struikelblok meer, zoals voor hun rasgenootjes in de districten.

En ook daar treft men reeds meer Nederlands aan dan men zou verwachten. Toen mijn jeep een keer muurvast in de modder van een binnenweg verankerd zat en alleen menșelijke hulp ons kon baten, meende een mij vergezellende Surinamer er goed aan te doen, de hulpvaardige Hindostaanse landbouwers in het Negerengels aan te spreken. De jongeren onder hen, zo tussen de twintig en de dertig jaar, antwoordden ons echter in behoorlijk Nederlands.

Ik voorzie dus een tijd, dat de speciale taak van de op te richten kleuterscholen overbodig geworden is, ook al leven er enkele tendenzen die werken voor behoud en uitbreiding van het eigene. Uiteraard is het na de oorlog sterk gegroeide nationale gevoel daaraan niet vreemd en niemand zal er iets op tegen hebben, dat 
dit eigene bewaard blijft; het Negerengels bv. bevat een schat van wijsheid in zijn spreekwoorden of odo's. Zolang men echter, tegen de meningen van prof. dr van LIER en dr FerRIER (beiden Surinamers) in, niet bewijzen kan dat dit eigene geschikt is voor een algemene omgangstaal, zolang zal men daarbuiten moeten zoeken naar datgeen dat bindt.

Historisch is deze taak weggelegd voor het Nederlands. Er zijn wel eens stemmen - invloedrijke stemmen zelfs - opgegaan voor een ander taal-medium: Engels en Spaans zijn genoemd. Bij aanvaarding van een dezer talen zou men een wijdverbreide en soms diepgewortelde kennis van het Nederlands moeten opofferen, een niett bepaald doelmatige werkwijze. Zeker, men is door zijn beheersing van de Nederlandse taal gebonden aan de Nederlandse cultuur; maar die Nederlandse cultuur is niet de slechtste. Men is door zijn kennis van het Nederlands beperkter in zijn toekomstmogelijkheden dan b.v. met een beheersing van het Engels of het Spaans. Maar... het Nederlandse onderwijs is er altijd op gericht geweest, deze belemmeringen op te heffen en deze goede traditie volgen wij hier na; niet voor niets wordt het Spaans onderwezen op de scholen voor M.U.L.O. en M.O. De talrijke, in het buitenland (en hiermede bedoel ik ook de gebieden buiten het Nederlandse taalgebied) uitzonderlijk goed geslaagde Surinamers bewijzen, dat onderwijs in het Nederlands geen belemmering behoeft op te leveren om te slagen in het leven, waar ook ter wereld!

Nederland heeft m.i. hier een duidelijke taak. Niet genoeg kan gedaan worden om mogelijk te maken, wat hierboven is uiteen gezet. De Stichting voor de Culturele Samenwerking tussen Nederland, Indonesië, Suriname en de Nederlandse Antillen doet reeds veel. Maar er is zoveel verzuimd in het verleden en de achterstand is zo groot! Op allerlei gebied, sociaal, economisch, cultureel, politiek. Op economisch gebied krijgt Suriname nu hulp via het Welvaartsfonds Suriname. Het zou de moeite lonen, indien Nederland een „Cultureel Fonds Suriname” stichtte, dat hielp, waar onze onderwijsbegroting noodwendig tekort moet schieten.

Want - over de hierboven ontwikkelde plannen is nu wel overeenstemming berreikt, maar de uitvoering is niet zo eenvoudig. Neem alleen het ,kleuterschool plan”. Dat vraagt: le Het bouwen van klassen bij de ruim tachtig bestaande districtsscholen. (Tussen haakjes: er is berekend dat we er nog zo'n 150 districtsscholen bij moeten hebben, voor we aan de behoefte voldaan 
hebben). 2e Het opleiden van de onderwijzeressen voor die kleuterklassen.

Uiteraard liggen de grote moeilijkheden op financiëel terrein. Het bouwen van 80 kleuterschooltjes - hoe eenvoudig ook van opzet - vraagt van de Surinaamse begroting, die in haar geheel om de 20 millioen schommelt, vrij veel. De benoeming van een 80, misschien 160 kleuterschool-onderwijzeressen vraagt op een totaal van even 900 leerkrachten bij het gehele onderwijs een procentsgewijs zeer sterke verhoging van de jaarlijks terugkerende uitgaven voor salarissen. Daarbij komt dan nog de opleiding; die is niet alleen moeilijk om het geld, dat er mee gemoeid zal zijn. Het blijkt minstens even lastig te zijn een leerkracht te vinden, die de leiding van deze opleiding in handen kan nemen. Reeds anderhalf jaar wordt er naarstig gezocht en nog is de geschikte candidate niet gevonden.

En toch moeten we deze weg op!

$\mathrm{Het} \mathrm{schoolbezoek}$

Het schoolbezoek verbeteren betekent elimineren van de oorzaken, die dat schoolbezoek belemmeren. Uiteraard kan Onderwijs weinig doen aan de vermelde ,lintbewoning”, waardoor de afstanden van school naar huis te groot worden. Bruggen slaan over de soms onstuimige rivieren ten behoeve van enkele tientallen schoolkinderen gaat ook niet en dus zullen die kinderen of in soms angstig wankele roeibootjes naar school moeten komen... o of thuis blijven.

Wel zal er bij de uitbreiding van het onderwijs op gerekend moeten worden, dat het de voorkeur verdient meerdere kleine scholen te stichten boven één grote, hoeveel bezwaren er ook aan die kleine tweemans-schooltjes kleven. Toename van het aantal leerlingen zal meer opgevangen moeten worden door het oprichten van een tweede school op enkele kilometers afstand dan door vergroting van de bestaande school, ook al is dat veel eenvoudiger en goedkoper.

Toch is de voornaamste verbetering alleen maar te verwachten van een andere mentaliteit ten opzichte van het onderwijs bij de ouderen. Dit te bewerkstelligen is mogelijk een taak van de bestrijding van het analphabetisme. Het staat voor mij vast, dat ouders, die zelf niet kunnen lezen en schrijven, het nut van geregeld schoolgaan voor hun kinderen niet kunnen inzien. Zijn zij die kundigheden wel machtig en is er daarnaast voor gezorgd, dat die verworven kennis kan functioneren - m.a.w. dat 
er voldoende en eenvoudige leesstof aanwezig is voor deze be"volkingslagen - dan zal het begrip voor geregeld-naar-schoolgaan kunnen groeien. Dan zal het ook niet meer kunnen gebeuren, dat het al dan niet naar school gaan afhangt van de wil van de jeugdige scholier. Een onaangenaam voorval op school - en het kind blijft een week thuis, of voorgoed. Geen haan die er naar kraait, behalve dan de onderwijzer, die op zijn tochten van (verplicht) huisbezoek nog probeert te redden, wat er te redden valt. Deden zij dat niet, het verbijsterend hoge verzuimpercentage zou ongetwijfeld nog hoger zijn.

Zeer stellig is ook de voertaalkwestie oorzaak van verzuim. Zolang tal van onderwijzeressen de nodige kennis van de omgangstaal (talen) van haar leerlingen ontbreekt en zolang zij ook de kennis van een juiste spreek-, lees- en taalmethodiek niet bezitten, zolang zal voor het gros van de leerlingen der eerste klas het schoolgaan een zó stom-vervelende geschiedenis zijn, dat ik me begrijpen kan dat ze maar liever thuis blijven. We trachten dit te verhelpen door b.v. in een klas met Hindostaanse kindertjes een Hindostaanse onderwijzeres te plaatsen. Maar lukken doet dat niet altijd en bij de Javaanse kinderen is het nog onmogelijk, aangezien het aantal Javaanse leerkrachten in heel Suriname op de vingers van één hand geteld kan worden. Het is voorgekomen, dat leerlingen graag naar school gingen omdat een bepaalde onderwijzeres, die hun taal wel verstond, in hun klas les gaf. Tof zij verhoogd werden en bij een ander kwamen, die niet zo knap was; toen bleven ze thuis. Bij het huisbezoek kwam deze reden te voorschijn en de leerlingen waren niet bereid, naar school terug te keren, tenzij zij weer bij hun vroegere onderwijzeres mochten zitten. Het zitten in een hogere klas gaven ze dan wel cadeau!

Misschien zal het ook noodzakelijk blijken, in de districten al het onderwijs maar niet gratis te geven. Ik weet - dit klinkt zeer reactionnair; dr FERRIER plaatst als motto in zijn dissertatie artikel 26 van de Universele verklaring van de Rechten van de Mens en daarin lezen we: het onderwijs zal kosteloos zijn. En toch - het is een ervaringsfeit dat veel te gemakkelijk gedacht wordt over hetgeen men zonder betaling verkrijgt. En een weinig ontwikkelde landbouwersbevolking, die bovendien op de penning is, zal zich wel tweemaal bedenken de kinderen niet naar school te sturen, als er toch voor betaald moet worden. En als men het onderwijs in de districten gratis wil blijven geven (let wel, óók aan kinderen van gegoede landbouwers) omdat het peil 
van het onderwijs nauwelijks betaling waard is, dan zou men in ieder geval kunnen proberen andere faciliteiten, die nu voor rekening van den lande komen (vervoer naar school b.v.) door de ouders te laten betalen. Ik ben niet de enige en ook niet de eerste die meent dat de geest van het ,lanti sa pai” (het gouvernement zorgt er wel voor) een hinderpaal is op de weg naar ontwikkeling van het land.

En - er zou nog een massa te verbeteren zijn aan de schoolgebouwen; om die zó aantrekkelijk te maken, dat de kinderen er met plezier naar toe komen. Wat vroeger in de districten aan schoolgebouwen werd neergezet, kan nauwelijks de naam van school dragen. Een aan alle kanten open ruimte zonder tussenwanden - ongeverfde banken vol inktvlekken - ruwe vloeren, soms van afgekeurde dwarsliggers gemaakt, neen, aanlokkelijk zijn onze districtsscholen niet. De journalist BAKKER schreef na zijn bezoek aan Suriname in een Nederlands periodiek: ,Wat Suriname nodig heeft is een vat petroleum om die scholen in brand te steken". Wel, ik aanvaard dat vat gaarne, maar dan mèt de fondsen om nieuwe en betere scholen te bouwen!

Want we kunnen het wel tegenwoordig. Er is een nieuw model tweemansschool, dat er zijn mag. We hebben in de Javaanse nederzetting Tamanredjo (district Commewijne) een vierklassige school neergezet, eenvoudig, zonder enige luxe, maar fris, prettig om te zien. En... het schoolbezoek is daar sinds de opening constant boven de $90 \%$ !

De opleiding van de leerkrachten

Het meest belangrijke probleem. Want wat wij ook van plan zijn met ons onderwijs, het zal alleen volvoerd kunnen worden als we beschikken over een voldoend onderlegd onderwijzerscorps.

Met de oplossing van dit probleem zijn we - vergelijkenderwijs - het verst gevorderd. Wij zijn zover, dat de dag niet ver meer is dat de geheel onopgeleiden, de zg. districtskwekelingen, vervangen kunnen worden door de in-ieder-geval-bevoegden, de hulponderwijzers. Maar ook deze zullen in de toekomst niet meer in de school staan. Gelegenheid om het examen voor de hulponderwijzersakte af te leggen is er nog tot 1952, daarna is het onherroepelijk uit. Wel zitten we dan nog met een groot aantal van deze leerkrachten, die door gebrek aan een goede vooropleiding zeer weinig kans hebben een hogere bevoegdheid te behalen. Voor hen is reeds nu uitgestippeld een reeks van herscho- 
lingscursussen, waarbij vooral op het terrein der opvoedkunde bijgespijkerd zal worden, wat aan hun opleiding mankeerde.

Reeds is ervaring opgedaan met het instituut herscholingscursus. Een 24-tal oudere en uitgezochte hulponderwijzers(essen) volgt reeds geruime tijd zo'n cursus en over het algemeen is het oordeel gunstig, aan beide zijden: van de opleiders zowel als van de opgeleiden.

Voor de hulponderwijzers, die een MULO-diploma bezitten, bestaat de gelegenheid om via een driejarige avondopleiding de onderwijzersakte te behalen. Dit is een zeer zware opgave voor hen: overdag zijn ze op school en het af te leggen examen zal niet minder kunnen en mogen zijn dan het eindexamen van onze drie-jarige dagkweekschool. Naar alle waarschijnlijkheid zal deze opleiding dan ook wel minstens vier jaar vragen.

De drie-jarige dagkweekschool! Dat was een belangrijke dag voor het Surinaamse onderwijs, toen die school op 1 December 1949 geopend werd. Heel schuchter, een enkele klas, nog zonder bevoegde leraren. $\mathrm{Nu}$, een jaar later, is er een nieuwe eerste klas bijgekomen van 30 leerlingen en beschikken we, dank zij een gelukkige combinatie met onze A.M.S., over een staf volledig bevoegde leraren. Ik ben er van overtuigd, dat deze Surinaamse Kweekschool zeer spoedig zal uitgroeien tot een grote school en het Surinaamse onderwijs zal voorzien van onderwijzers, niet alleen beter onderlegd dat hun voorgangers, maar tevens bezield van een juiste geest. Want ook daar streeft onze kweekschool naar, en met succes.

Het is niet eenvoudig geweest, deze kweekschool te laten beginnen. En nog zijn alle moeilijkheden niet opgelost. Een grote belemmering wordt ondervonden van het feit, dat door het bestaan van de hulponderwijzersakte men ,in de verdienste" kon zijn tijdens de (avond)studie voor de onderwijzersakte. Aangezien in Suriname - als overal elders - de aanstaande onderwijzers ook komen uit de kringen, niet zo rijk gezegend met aardse goederen, is dit altijd een belangrijke bijkomstigheid geweest. En wie nu naar de drie-jarige dagschool gaat, die weet, dat de verdiensten op zijn minst genomen pas over drie jaar kunnen komen. Door de Landsregering is dat ook ingezien en men is zeer schappelijk met het verlenen van vrijstellingen van schoolgeld en het verstrekken van $\mathrm{zg}$. boekengeld.

We zullen er komen, niet alleen met onze kweekschool, maar ook met het Surinaamse onderwijs. Alleen, we moeten ons bewust zijn dat deze opbouw, deze herbouw, grote inspanning en belang- 
rijk veel geld zal kosten. Wie denkt er in enkele jaren te kunnen zijn, zal bedrogen uitkomen en daardoor wellicht de moed verliezen om door te zetten. Wie denkt, dat alles van zelf zal gaan, zal bemerken dat alleen dan resultaat geboekt kan worden als ieder meer doet dan hij denkt dat hij doen kan. En wie denkt, dat dit opbouwprogram (waarbij ik nog niet eens gesproken heb over de vraagstukken die opgelost moeten worden op het gebied van het vakonderwijs!) geheel uit onze bescheiden Surinaamse begroting bekostigd kan worden, die verwijst de verwezenlijking van dit alles wel naar een heel verre toekomst. Snelle en afdoende opbouw is alleen mogelijk met hulp van buiten, van Nederland in de eerste plaats.

Wie begint er aan een Cultureel Fonds Suriname?

Paramaribo, Dec. 1950.

\section{SUMMARY}

The author, technical director of the department of education in Dutch Guiana since 1946, discusses the problems of the educational system in that country as it used to be up till 1948 and as seen from the following angles: the complexity of the population of Creoles, Indians, Indonesians and several other groups; the difference in level of similar types of schools (town and district schools, poor and well-to-do pupils) and the general level of education (at most three grades beyond the primary school, some vocational training); the typical West Indian environment of the children and the lack of appropriate textbooks (those used were the same as in Holland!); the medium (Dutch in stead of the vernaculars; bi- and multi-linguism); attendance, or rather, absenteism; teacher training.

A report on the possible reorganisation of education in Surinam by Mr. D'HAENS was published in 1947 and taken by the Government as a basis for practical measures in 1948.

Following the same headings as used in his analysis, the author then discusses the steps taken and the many wishes still unfulfilled. The organisation has been improved by separating the primary school (six years) from the two following grades and from the secondary school of four years. The latter has got an entrance examination now. A real secondary school has been created (six years) and the very restricted primary education in the districts is bound to disappear with time. 
Writing of textbooks adapted to the environment is very difficult as long as publishing is on a commercial basis only the numbers being too small (33.000 schoolchildren, all-told). Competent authors, moreover, are difficult to find.

None of the vernaculars (Negro-English, Hindi, Javanese) being sufficiently prevalent, Dutch has to be used as a medium. English and Spanish are being taught in secondary schools. The author, however, stresses the necessity for using the vernacular in the first contact of the child with the school (either in kindergarten or in lowest grade).

Attendance can be stimulated by having more (small) schools rather than one larger one in districts where population density is low and distances long. Parents have to be educated (illiteracy control); more teachers have to be trained so as to have Indian and Indonesian teachers for Indian and Indonesian children; schools and/or other facilities should preferably not be completely free; schoolrooms will have to be more attractive.

Teacher-training has re-started in a new three-year training college (opened December 1949) and in rehabilitation courses for teachers with insufficient previous training.

Much remains to be done. Surinam is willing but not able to do it unaided. 